\title{
Enhancing Reading Skills for Saudi Secondary School Students through Mobile Assisted Language Learning (MALL): An Experimental Study
}

\author{
Muhammed Salim Keezhatta ${ }^{1} \&$ Abdulfattah Omar ${ }^{1}$ \\ ${ }^{1}$ Department of English, Prince Sattam bin Abdulaziz University, Alkharj 11942, Kingdom of Saudi Arabia \\ Correspondence: Abdulfattah Omar, Department of English, Prince Sattam bin Abdulaziz University, Alkharj \\ 11942, Kingdom of Saudi Arabia. E-mail: m.keezhatta@psau.edu.sa
}

Received: August 2, 2018 Accepted: August 26, 2018 Online Published: January 7, 2019

doi:10.5539/ijel.v9n1p437～URL: https://doi.org/10.5539/ijel.v9n1p437

\begin{abstract}
This study addresses the issue of integrating mobile-assisted language learning (MALL) systems into L2 reading instruction in the Saudi secondary schools in order to improve the reading comprehension skills of struggling EFL students. The focus is to find out whether students' language performance is accelerated by using MALL together with teacher instruction versus conventional instruction alone. In order to assess the effectiveness of MALL systems and activities in improving reading comprehension skills in EFL contexts, an experimental study was carried out where 120 participants of grade ten students in four public secondary school of Riyadh District in Saudi Arabia were randomly divided into two groups: experiment and control. Reading skills of the participants' were measured by pre-test and post-test by a panel of three national experts. The comparison between the experimental group and the control group pinpoint that MALL materials and systems improve reading comprehension skill among EFL students. The findings indicate clearly that there was a significant difference between MALL users and nonusers in favour of the experimental group $(p<.05)$. It can be then generalized that MALL systems and applications in general provide a motivating learning environment for teaching reading which has its positive implications on improving the reading skills of students.
\end{abstract}

Keywords: MALL, EFL reading, second language acquisition (SLA), vocabulary recognition, vocabulary acquisition, vocabulary retention, word decoding

\section{Introduction}

This study addresses some of the problems raised by recent reports written by the Ministry of Education in Saudi Arabia in 2017 which indicated that there are many problems with teaching English as a second language in the Saudi schools. The issue was later investigated more extensively by King Abdullah Project for Improving Public Education known at Tatweer. The reports issued by the two bodies stressed that there was a wide gap between learning outcomes and students' linguistic performance. They attributed this gap to the curriculum design and the way it was delivered to the students. The reports also pointed out that many teachers were still using traditional methods which proved to be useless and ineffective. The reports stressed the importance of improving students' language and communication skills by means of fostering effective teaching and assessment strategies that make the best use of the technology advances in both teaching and learning processes. Earlier, Assagheer (2011) discussed the very poor outcomes of English language instruction in middle and secondary schools. He indicated that students' achievement in the acquisition of English as a second language in middle schools was just 34, 15per cent and in secondary or high scores 31 per cent. He attributed the low achievement levels primarily to psychological reasons (lack of motivation and confidence). He pointed out that students have negative perceptions about learning English. They are quite convinced that it impossible for them to learn English. He also referred to many obstacles within the Saudi educational system such as the poor curriculum design, the poor training of teachers, the lack of educational technology devices, the assessment system, and the use of old-fashioned and traditional teaching methods.

In the face of this, the present study attempts to fill in the gap in English language instruction in the Saudi schools. The main hypothesis is that MALL systems and applications can be motivating for the EFL students so the adoption of MALL systems in the Saudi context will reduce many of the problems and challenges within 
EFL reading in the Saudi schools. The implication is that MALL offers a wide range of possibilities such as motivation, learner's autonomy, and increased interactivity (Bush, 2008; Hubbard, 2008). In order to test this hypothesis to the Saudi context, the study proposes a pretest-posttest study design where participants in the experimental group will receive a MALL supplementary course for improving their reading skills in relation to vocabulary recognition, acquisition, and retention and overcoming reading problems and challenges in the Saudi context. The study thus is an attempt to meet the reading comprehension needs of EFL learners in Saudi schools via proposing an effective instruction method based on MALL methodology for students in secondary schools. Being aware of the complexities of comprehension assessment, the researcher suggests reliable and objective methods of assessment. In this way, it can be said that the immediate contribution of this study will be a local contribution since its relevance is in Saudi education system. There has been a misconception that learning English has a negative impact on Arabic use. That is why, many parents did not encourage their children to learn English and children themselves were not motivated to learn it. So, the study is concerned with enhancing students' motivation towards learning English which can be positively reflected on their vocabulary recognition, acquisition, and retention.

\section{Research Problem}

Numerous studies have identified many problems with the EFL students' achievement and performance in relation to reading tasks in L2 classrooms in general and in Saudi schools in particular (Al-Jarf, 2007; Al Nooh \& Mosson-McPherson, 2013; Morris, 2011). These studies indicate that L2 learners struggle with comprehending reading passages in English. These problems were attributed to many reasons including lack of confidence, lack of linguistic knowledge, vocabulary recognition and retention, boring reading materials, poor question design in student textbooks, and traditional teaching practices.

Another main problem, however, is the lack of feedback and support mechanisms that can supplement teaching reading skills. Within the conventional setting, there is usually no individualized feedback given to the students while doing reading tasks (Al-Jarf, 2007; Assagheer, 2011). It is often difficult for a teacher to give students quick feedback since in many cases the number of students in each class is relatively big. This results anyway in some problems that have negative impacts on reading classes. Some teachers are only concerned with providing help and support only for skilful readers. Others may be concerned with providing help and support for struggling readers. In both cases, not all students grow and develop since all students need feedback and support but these needs differ from one student to another (Ediger, 1999 ). Al- Jarf (2007) argues that reading instruction in Saudi Arabia is whole-class instruction that does not meet the students' needs at both the frustration and accelerated levels. Students are not involved in group discussions and usually they are not permitted the opportunity to communicate and interact with their peers and teachers. Similarly, Masadeh (2015) argues that in the Saudi schools, most of the teachers support neither fluent readers nor struggling ones.

A third problem that is thought to be unique to the educational structure in the Kingdom of Saudi Arabia is that the Saudi educational system traditionally concentrated on Islamic teachings giving no priority or importance to teaching foreign languages. There was a wrong perception that English learning as a second language particularly at very early ages may affect adversely the children's acquisition of their native language. Arabic is highly celebrated in Saudi Arabia as it is the language of the Holy Quran and Saudi Arabia itself is the location of the Holy Mosques and the motherland of Islam and the Quran. This is reflected in negative ways on the students' attitude towards learning English. Many students and families still think English is not important for their overall academic achievement. The implication is that there are different problems that make it difficult for EFL learners in Saudi schools to develop their language skills in an appropriate manner. The EFL learning environment is not motivating for the students for many reasons including the conventional teaching methods, unqualified teachers, boring learning materials, and cultural factors. In other words, different factors in the Saudi context-curriculum of the English education, culture of teachers, environment of the school, and policy of education - and the complex interrelationships among these factors led to the poor performance of the EFL students in the Saudi schools.

In the light of the above mentioned problems, this study is concerned with addressing the problems with EFL reading in the Saudi schools. According to ESL researchers, reading is important for academic success (Adler, 2004; Mahrooqi \& Adrian, 2014). In the same way, Yang (2014) argues that reading fluency is important in the linguistic development of EFL learners. This comes in an agreement with Krashen's theory in the sense that reading creates a valuable influence to developing language acquisition, benefiting the confidence and competence of learners (Krashen \& Torrel, 1983). The study is based on the hypothesis that the integration of mobile-assisted language learning (MALL) programs into English language instruction programs in Saudi Arabia will create new and effective practice environments. The latest advances in computer and mobile 
technology and the integration of these technologies and teaching philosophies and practices seem to be effective in dealing with such problems and challenges. The adoption of MALL approach is hoped to turn these challenges into real opportunities. The assumption is that MALL methods offer effective solutions to these problems. MALL programs and tools can enhance students' motivation in EFL learning, improve students' academic achievement and vocabulary recognition, acquisition and retention, and increase learners' self-confidence (Johnson, Perry, \& Shamir, 2010; Knaack, 2003). According to Hsu (2013), MALL has become a admired method of language learning and teaching, particularly within the framework of EFL. He also adds that students generally have positive attitudes towards the use of technology, including mobile phones, in L2 learning. In this, he recommends the use of mobile assisted language learning systems in L2 classrooms. Similarly, Sanz, Levy, Blin and Barr (2015) argue that the network-based language learning, mobile-assisted language learning, implementation of technology-enhanced language learning, and so on, has a close relationship with sustainable learning. One main advantage with MALL systems which is thought to be useful for the purposes of the study too is that MALL systems and applications centre on students' individual needs, learning styles, and preferences (Godwin-Jones, 2013; Son, 2014). MALL designers and researchers realized the idea that there are differences in learning styles of students that need to be addressed in designing learning materials (Gobel \& Kano, 2014). The idea is that every learning style involves or engages different portions of the brain because it includes supplementary knowledge acquisition, rather than merely using the brain for learning. Thus, students recall more of what they learn. Researchers employing brain-imaging technologies such as MALL have been capable of discovering the main extent to which the brain adapts to each learning style. It can be claimed then that the use of MALL is useful in addressing the needs of struggling students and those with poor linguistic performance where traditional methods did not work well.

\section{Research Questions}

Numerous approaches have been proposed in the critical theory of reading comprehension instruction; nevertheless, there are still many problems and challenges EFL learners and language instructors face in teaching classrooms. Even more, every now and then new problems arise as a result from the complicated learning environments we witness today. It is necessary then for teaching theorists to develop teaching strategies and educational practices in a way that accommodates changes and challenges within learning communities. With the rapid developments in technology, it becomes now possible to make use of the technological advances to improve language skills to EFL learners. In spite of the increasing importance of the integrating technology and MALL applications and systems into L2 learning, very little has been done in relation to the use of MALL systems and applications within the Saudi learning environments. In the light of this argument, this study addresses the following main research question.

Is it conceptually useful for MALL applications, software, and resources, to be incorporated in reading instruction in the classroom to enhance learning outcomes of the EFL students (especially those who have obvious reading problems) in Saudi secondary schools?

This broad research question entails a number of other sub questions that can be listed as follows.

- What is the effect of using MALL resources, systems, and applications on EFL learners in Saudi secondary schools? And whether MALL systems are effective in getting students motivated and enthusiastic about reading in English? In other words, what is the impact of mobile-based activities and tasks on EFL learners' attitude and motivation towards learning L2 reading comprehension?

- Are teaching approaches which integrate MALL methods effective in giving useful feedback and support for struggling readers in order to improve their achievement in reading tasks?

- Is it possible to monitor the progress of EFL students in Saudi schools using realistic, reliable, and objective methods based on MALL software and resources?

\section{Literature Review}

The recent years have witnessed an increasing use of the mobile technology in teaching and learning foreign languages. Hsu (2013, p. 197) argues that students today are known as "digital natives". Students use the mobiles and the Internet all their lives. Compared to the past, larger numbers of teachers and second language learners use the mobile in language teaching and learning. This can be obviously attributed to the advent of the multimedia computing and the internet which made the learning process both accessible and interesting (Hubbard, 2009). It is evident that there is a need at present to insure that curriculum demands are met and integrated into different contexts, which may not be achievable without teachers with a high level of digital literacy (Bates, 2014). The use of mobile and computer technology by several universities, colleges and schools 
across the globe have brought the MALL tools to teach the students EFL as they believe that these will revolutionize the pedagogy of EFL and create the near-native EFL speakers. MALL is being termed as revolution in the field of language teaching pedagogy. Internet access has encouraged and facilitated information distribution. It allows education to occur anytime, anywhere.

In relation to EFL reading, numerous studies have indicated that MALL is useful in reading instruction as it is reported to positively influence the reading skills of L2 learners (Bangs, 2011; S Bax, 2011; Bhatti, 2013; Gupta \& Schulze, 2011; Hubbard, 2009). Hubbard (2009), for instance, showed that on screen activities of word recognition and decoding drills were source of great interest and fun for the students who benefited the MALL teaching in terms of improving the L2 reading skills within a short period of time compared to the teacher-led method of teaching. Sun (2017 agrees that the adoption of MALL improved learners' reading abilities in comparison to the old-style schoolroom. They advised that the electronic setting (MALL environment) changed the EFL student's role in the reading class, the nature of the EFL teacher's, and created a different teacher-student relationship. These findings suggest that MALL has the ability to affect the L2 reading skills positively and can show higher degree of improvement in L2 learner's reading process compared to the conservative teaching method. These results confirm the hypothesis that the development of MALL programs is important for improving the L2 reading skills for Saudi students (Park, Zheng, Lawrence, \& Warschauer, 2014).

The literature also suggests that the integration of MALL is useful for improving reading comprehension skills of struggling readers. Gangaiamaran and Pasupathi (2017) reported that integration of MALL materials into the L2 reading classrooms positively affected the reading skills of L2 learners at their low-level in learning process. The study concluded that incorporation of MALL materials into the classroom favoured the students to interact with their queries in more entertaining way rather than the teacher based method in which their queries were not dealt properly due to lack of time and shyness on the part of students. Sato and Suzuki (2013) indicate that the use of multimedia and MALL applications has the effect of freeing more working memory for learning decoding and word recognition skills. They explain that freeing more working memory for decoding skills is essential for automation process of word decoding leading to improve the overall L2 reading process. This helps students to retain more words, recall word meanings more quickly, and achieve higher scores in reading comprehension tests. In spite of its effectiveness, however, MALL is not effectively or systematically used in the Saudi schools and very little has been done on the use of it in the Saudi context. This study attempts to bridge this gap in literature by means of testing the effectiveness of MALL applications in improving the skills of vocabulary recognition, acquisition, retention as well as word decoding of struggling readers in the Saudi secondary schools.

\section{Methodology}

\subsection{Methods}

To address the research questions, a hybrid use of language learning and MALL is considered in the context of developing a supplementary course based on a MALL application for EFL learners in Saudi secondary schools. The methodology used is based on introducing linguistic information accompanied with visual and multimedia content, in order to enhance the learner's interest, motivation and interactivity. The content is syllabus-based. That is, it is based on the English language course students are required to pass in the Saudi secondary schools. The themes and topics are adopted from the textbook students are studying.

The Ivers and Barron (2014) model of building multimedia projects in classrooms is adopted for the system implementation of this study. Ivers and Barron (2014) outlined a scheme for implementing technology-based systems which they labelled DDD-E: Decide, Design, Develop and Evaluate. The authors propose the DDD-E model as a framework for selecting and planning multimedia projects, using presentation and development tools, managing graphics, audio, and digital video, creating Web pages, and evaluating student work. The model provides effective and easy to be applied methods for instructional planning. It has been positively employed in many multimedia schemes and as has the ability to familiarise first-hand instructive skills (Ivers \& Barron, 2014). The rationale of selecting the Ivers and Barron model is that it is a systematic and reliable approach for instructional design. It offers a step-by-step approach for designing, producing, and assessing multimedia projects in the classrooms. Furthermore, the model has proved effective in the design and development of digital content creation (Ampa, 2015).

\subsection{Procedures}

The design used in this study is the pretest-posttest control group design where 120 students in four secondary schools in the District of Riyadh, the Capital city of Saudi Arabia were selected for the purposes of this study. These were selected based on teacher ratings of the students' classroom behaviour and reading scores on a standardised test. Only very low-level students (whose scores range from 0-1 out of 5) were selected. Both the 
pretest and posttest are syllabus based and they were reviewed and validated by curriculum experts in the Ministry of Education in Saudi Arabia.

An initial step in the development of reading comprehension skills to EFL learners is to have a prior knowledge of their performance in responding to reading comprehension tasks and drills. In Spring 2016, a preliminary analysis was undertaken to examine the features of the EFL reading instruction in one of the Saudi secondary schools. The goal of this field study was to evaluate teaching reading to EFL students and to provide a vision of how to develop a reliable supplementary MALL course which can effectively meet the learners' needs. Class observations and teacher consultations were the key foundations for the gathering of records. Furthermore, the reading class plan, the curriculum, manuals, the appearance ratio and reproductions of preceding examinations were also gathered as records.

Direct observations provided a thorough and contextualised image of a characteristic reading schoolroom at one of the Saudi secondary schools. Typically, with such a significant number of students (40-50), lessons were kept simple. Consequently, group work between students rarely happens, and when it did, it had a tendency to be limited in length. It was also observed that reading instruction was teacher-centred and textbook-focused. The teacher, or two or three students, read the path and then the teacher confidently debates the concepts with a number of students. The students' standards, approaches, or thoughts were not often requested and students did not offer their opinions readily. When students spoke the teacher interrupted, so the student's turn was short-lived rather than being combined in the class or employed to inspire additional conversation. Free-unbroken debate between students and the teacher was unusual. After reading, students typically worked separately on the reading assignment and later validated their responses with the assistance of the teacher who was unable to assign a phase to scrutinise their efforts and offer personalised responses owing to the restrictions on the schoolroom area. Thus, each individual student did not have an opportunity to contribute. Consequently, there were distinct differences between students.

Typically, students did not receive the same amount of attention from the teacher. They are unable to gain face-to-face contact with their teacher who typically focused on good readers who were seated closer to him in the room. Students seated closer the rear of the schoolroom are perceived as evading interaction with their teacher; the further they are from their teacher the less they anticipate being asked to contribute. These can be classified as struggling readers. It was also observed that students had the tendency to be awkward when talking in the classroom and they are often concerned about showing their errors when they are so visible to their peers. Therefore, their responses have the tendency to be inadequate or quiet. Throughout the learning process, students established their dependence. There was no, or restricted, disclosure to reliable reading resources. This was related to the absence of other learning materials in the school such as the internet, an up-to-average key archive or even a schoolroom archive. The only educational instrument, which could be accessed in the reading schoolroom, was a whiteboard, and it was not employed enough. An additional obvious aspect of the school reading schoolroom was related to the use of L1. The teachers in the school used Arabic (L1) for explaining vocabulary, sentence structure, and overall meaning. One major problem with this approach is that the use of English as a medium was very limited which had its negative implications on the students' performance. A final point that can be mentioned here is the attendance percentage. Teachers complained that the attendance percentage of the students in English language classes in general and reading in particular was disappointing. One teacher reported that it was only story classes that attracted the attention of students. Generally, teachers were not happy with the students' attendance percentage in reading classrooms. In this setting, students' ability to read English was really critical.

For objectivity and reliability reasons, a reading comprehension pre-test was conducted for all the participants in the study. Reading assessment is a recognised methodology for judging the reading ability of the students, with results conveyed from his/her reading performance at his/her specific grade level. Assessment includes, paper-and-pencil tests publicized by the national and recognised institutions, standard checklists made especially for a student to read out loud; and other recognised methods. The aim was to evaluate a student's reading fluency, accuracy, expression and comprehension to make a determination of the reading ability of the students. Assessments which do not offer significant improvements in results may be used in combination with other assessments to increase performance levels. Institutions, based in MOE policies and procedures are encouraged but not required to select effectiveness and to use multiple methods of assessment.

Secondly, a reading improvement plan for Grade 10 students was developed. It included additional hours of reading practice and instruction outside the regular school day during the academic year. The experimental group received a mobile-based course while the control group received the same content but using printed materials. The supplementary course addressed the problem of vocabulary recognition, word decoding, and inability to say 
words correctly. The system provided an easy-to-use automated speaking glossary. That was very effective and participants in the experimental group were able to recognize vocabulary and say words correctly after finishing the course. The course provided the students with the opportunity to separately read sentences and short passages with the help of their teacher. So it developed their own self-regulation and endorsed their independence. Students also were given the opportunity to mark their own choices, grow at their own pace, and have the liberty to mollify their dissimilar education prerequisites and benefits. This could be attained by adding diverse literature from numerous materials and by giving numerous kinds of assistance and management choices. Finally, a posttest was conducted in order to measure the effectiveness of the proposed system.

\subsection{The Participants}

120 students attending Grade 10 in four of the Saudi public secondary schools participated in this study. Participants were divided into 2 groups, a controlled group and an experimental group. The participants were divided into two groups, 60 students each. In order to ensure that the two groups were equal, two prior tests were carried out. They addressed two variables: intelligence as well as social and economic factors. This is to make sure that the populations have the same variance so that the final findings are objective and reliable. Levene's Test for Equality of Variances, an inferential statistic, was used to assess the equality of variances for the two variables (intelligence as well as economic and social factors) calculated for the two groups (experimental and control). This is a common test which is used before making a comparison to make sure that the independent variable (supplementary course) is significant in determining the level of students' performance pre and after the supplementary course. In Levene's Test for Equality of Variances, the assumption is that all groups have the same or similar variance unless the $p$ value is less than .05 .

Table 1. Homogeneity of variance test of intelligence

\begin{tabular}{|c|c|c|c|c|c|c|}
\hline & & $\mathrm{N}$ & Mean & Std. Deviation & \multicolumn{2}{|c|}{ Std. Error Mean } \\
\hline \multicolumn{2}{|c|}{ Experimental } & 60 & 44.63 & 1.957 & \multicolumn{2}{|c|}{.253} \\
\hline \multicolumn{2}{|c|}{ Control } & 60 & 44.45 & 2.062 & \multicolumn{2}{|l|}{.266} \\
\hline \multicolumn{7}{|c|}{$\begin{array}{l}\text { Levene's Test for Equality of Variances } \\
\text { t-test for Equality of Means }\end{array}$} \\
\hline \multirow[t]{2}{*}{$\mathrm{T}$} & \multirow[t]{2}{*}{ Df } & \multirow[t]{2}{*}{ Sig. (2-tailed) } & \multirow[t]{2}{*}{ Mean Difference } & \multirow[t]{2}{*}{ Std. Error Difference } & \multicolumn{2}{|c|}{$\begin{array}{l}\text { 95\% Confidence Interval of the } \\
\text { Difference }\end{array}$} \\
\hline & & & & & Lower & Upper \\
\hline .500 & 118 & .618 & .183 & .367 & -.543 & .910 \\
\hline .500 & 117.679 & .618 & .183 & .367 & -.543 & .910 \\
\hline
\end{tabular}

Results indicate that the values of each group are very similar. The mean value in Group 1 which is the experimental group is 44.63 with standard deviation 1.957 and in group 2 which is the control group is 44.45 with standard deviation 2.062. The implication is that there is no significant difference between the members of each group. They scored very similar scores in the intelligence test. The assumption, therefore, is that the intelligence variance within the population or each of the two groups is equal. Here the mean difference is between the two groups is .183 with standard deviation .367 which is of no significance. It won't be claimed then intelligence is determinant or an important distinctive variable in the students' scores. Following the same procedures, all participants in the two groups had a test to assess their social and economic background. The rationale is that we need to make sure that no significant economic and social differences between the population or the participants in each group which may have its impact on the final results of the pretest and posttest.

Table 2. Results of the homogeneity of variance test of social and economic background

\begin{tabular}{|c|c|c|c|c|c|c|}
\hline & & $\mathrm{N}$ & Mean & Std. Deviation & \multicolumn{2}{|c|}{ Std. Error Mean } \\
\hline Expe & & 60 & 36.63 & 1.957 & \multicolumn{2}{|c|}{.253} \\
\hline Cont & & 60 & 36.53 & 2.021 & \multicolumn{2}{|l|}{.261} \\
\hline \multicolumn{7}{|c|}{$\begin{array}{l}\text { Levene's Test for Equality of Variances } \\
\text { t-test for Equality of Means }\end{array}$} \\
\hline \multirow[t]{2}{*}{$\mathrm{T}$} & \multirow[t]{2}{*}{$\mathrm{Df}$} & \multirow[t]{2}{*}{ Sig. (2-tailed) } & \multirow[t]{2}{*}{ Mean Difference } & \multirow[t]{2}{*}{ Std. Error Difference } & \multicolumn{2}{|c|}{$\begin{array}{l}\text { 95\% Confidence Interval of the } \\
\text { Difference }\end{array}$} \\
\hline & & & & & Lower & Upper \\
\hline .275 & 118 & .784 & .100 & .363 & -.619 & .819 \\
\hline .275 & 117.878 & .784 & .100 & .363 & -.619 & .819 \\
\hline
\end{tabular}


In this test, the mean difference between the two groups is 36.63 with standard error of difference .363 which indicates that there are no significant differences between the two groups in terms of the social and economic variables. The implication in this context is that final results are expected to be objective and reliable.

\subsection{System Architecture}

The proposed system was designed in order to improve students' skills in relation to automatic decoding, as well as vocabulary recognition, acquisition and retention which are important elements for reading fluency. The rationale is that reading comprehension is based in the first place on vocabulary knowledge: "lack of vocabulary remains one of the major obstacles for the ESL and EFL reader" (Birch, 2015, p. 128). Therefore, the proposed system is designed in a way that is both motivating and easy-to-use for increasing students' vocabulary knowledge.

The system is based on the .NET platform, and has been developed using Silver light development tools, and C+ and VB .NET as programming languages. The entire designing coding and testing was done within MicrosoftVisualStudio.Net2010IDE. Silver light is a cross-browser plug-in that provides interactive media and rich business applications, which can be hosted using different browsers and run on a variety of operating systems. Silver light builds on the. Silver light allows developers to use powerful development tools to build and develop usable, rich and interactive applications to enhance user experiences and achieve users' goals.

\section{Results}

Generally speaking, all the participants in the pre-test, whether in the experimental or control group were unable to respond positively to the test questions. They had noticeable problems with vocabulary recognition and word decoding. Results in the pre-test are represented as follows. The marks of the experimental group ranged between $0-5$ out of 20 and it was the same for the control group whose scores ranged between 0 and 5 as well. It is obvious then that there is no significant difference in the scores of each group. This suggests that their reading performance is very similar. This again is statistical evidence that all the participants were equal in receiving the same sort of education and they were subject to the same teaching practices and learning resources. This is shown in the tables below.

Table 3. T-test for comparing the scores of the experimental and control groups in the pretest

\begin{tabular}{|c|c|c|c|c|c|c|}
\hline & & $\mathrm{N}$ & Mean & Std. Deviation & \multicolumn{2}{|c|}{ Std. Error Mean } \\
\hline Expe & & 60 & 44.63 & 1.957 & \multicolumn{2}{|c|}{.253} \\
\hline Contr & & 60 & 44.45 & 2.062 & \multicolumn{2}{|l|}{.266} \\
\hline \multicolumn{7}{|c|}{$\begin{array}{l}\text { Levene's Test for Equality of Variances } \\
\text { t-test for Equality of Means }\end{array}$} \\
\hline \multirow[t]{2}{*}{$\mathrm{T}$} & \multirow[t]{2}{*}{$\mathrm{Df}$} & \multirow[t]{2}{*}{ Sig. (2-tailed) } & \multirow[t]{2}{*}{ Mean Difference } & \multirow[t]{2}{*}{ Std. Error Difference } & \multicolumn{2}{|c|}{$\begin{array}{l}95 \% \text { Confidence Interval of the } \\
\text { Difference }\end{array}$} \\
\hline & & & & & Lower & Upper \\
\hline .500 & 118 & .618 & .183 & .367 & -.543 & .910 \\
\hline .500 & 117.679 & .618 & .183 & .367 & -.543 & .910 \\
\hline
\end{tabular}

As indicated in the table above, the mean values of the experimental group is 44.63 and with a standard deviation 1.957 and 44.45 with a standard deviation 2.062 in the control group. The mean difference between the two groups is .183 and .367 in the standard error of difference. This suggests that the two groups are almost equal. Some of the students got zero and the highest mark was 5 out of 20 in the two groups as shown below.

Table 4. Descriptive statistics of the students' scores in the pretest

\begin{tabular}{cccccc}
\hline \multicolumn{5}{c}{ Descriptive Statistics } \\
\hline & $\mathrm{N}$ & Minimum & Maximum & Mean & Std. Deviation \\
\hline Experimental & 60 & .00 & 5.00 & 2.3167 & 1.52373 \\
Control & 60 & .00 & 5.00 & 2.1667 & 1.23737 \\
Valid N (listwise) & 60 & & & & \\
\hline
\end{tabular}

As for the post-test, the scores of the experiment group ranged between 12 and 17 out of 20 . It should be noted that the highest mark of the experiment group in the pre-test was 5. So there is a significant difference between 
the scores of the experiment group in the pre-test and post-test. There is also a significant difference between the experiment and control groups in the post-test where the marks ranged between 0 and 7 .

Table 5. Descriptive statistics of the students' scores in the posttest

\begin{tabular}{|c|c|c|c|c|c|c|}
\hline & & $\mathrm{N}$ & Mean & Std. Deviation & \multicolumn{2}{|c|}{ Std. Error Mean } \\
\hline \multicolumn{2}{|c|}{ Experimental } & 60 & 13.12 & 1.497 & \multicolumn{2}{|c|}{.193} \\
\hline \multicolumn{2}{|c|}{ Control } & 60 & 2.00 & 1.135 & \multicolumn{2}{|l|}{.147} \\
\hline \multicolumn{7}{|c|}{$\begin{array}{l}\text { Levene's Test for Equality of Variances } \\
\text { t-test for Equality of Means }\end{array}$} \\
\hline \multirow[t]{2}{*}{$\mathrm{T}$} & \multirow[t]{2}{*}{ Df } & \multirow[t]{2}{*}{ Sig. (2-tailed) } & \multirow[t]{2}{*}{ Mean Difference } & \multirow[t]{2}{*}{ Std. Error Difference } & \multicolumn{2}{|c|}{$\begin{array}{l}95 \% \text { Confidence Interval of the } \\
\text { Difference }\end{array}$} \\
\hline & & & & & Lower & Upper \\
\hline 45.841 & 118 & .000 & 11.117 & .243 & 10.636 & 11.597 \\
\hline 45.841 & 109.989 & .000 & 11.117 & .243 & 10.636 & 11.597 \\
\hline
\end{tabular}

\section{Discussion}

The main problem of this study was: How can MALL improve students' reading skills? Prior observations and teacher interviews indicated that students were passive recipients of knowledge. This problem was considered when designing the MALL supplementary course. In this course, students were given the opportunity to communicate with each other and with their teachers. It was also reported that the incorporated tasks were both stimulating and applicable. The aim of the MALL supplementary course was to motivate and sustain students' attention and participation in the incorporated tasks. So the course addressed some of the problems associated with poor turnout and the lack of schoolroom contributions and collaboration.

Results reflect clearly that the overall performance of students was improved after the mobile-based supplementary course. This finding agrees with the main bulk of the MALL literature. Sato and Suzuki (2013) argue that MALL applications are very effective in improving reading performance of EFL learners. In our case, the use of mobile-based activities improved the students' skills in relation to vocabulary recognition and word decoding. This agrees with Sato and Suzuki's (2013) argument that MALL systems, applications, and activities lead to better comprehension in L2 reading by means of enhancing vocabulary learning. It should be noted however that mobiles by themselves are not automatically motivating to students. It is the way MALL activities are designed. In this way, MALL systems and applications must be well-designed and appropriate for the course purposes, the students' levels, and motivation.

According to the researcher's direct observations, students liked to be involved in doing tasks, watching images, and working independently. It was clear that students in the experimental group showed increasing interaction in the classroom during the supplementary course. This interaction was reflected in student-student and student-teacher communication. It was evident that students had a positive attitude towards MALL activities and L2 learning. According to Asim and Majeed (2013), there is a strong correlation between the integration of MALL activities into English language classrooms. In their experimental study of the relationship between motivation and MALL environments, they argue that the motivation and interest among the students were high. This agrees with Pu's (2009) argument that the use of MALL led to higher learning motivation rates among the Chinese EFL students.

It can be claimed then that traditional methods are not effective in reading instruction. They are not motivating. Students are just passive recipients and there is no opportunity for them to communicate in English. The finding of the study clearly reveals the delimiting elements on the teaching methods to get the desired achievement by the students in reading and to meet needs of the readers. The idea that teachers explain and deliver the information in Arabic represents a real challenge too. Therefore, mobile-based activities should be incorporated so study materials are more motivating. This finding agrees with many studies that students can learn better when they enjoy the teaching strategy.

The age at which students start learning English should be considered too. The findings of the study indicate clearly that there are many struggling readers in the Saudi secondary schools. One of the reasons is attributed to the idea that students started learning English too late. According to the Saudi system of education, they started learning English only when joined the middle school. Therefore, the educational policies concerning teaching English as a second language should be reconsidered. 


\section{Conclusion}

The results of the pre- and post- tests revealed that the MALL supplementary course design for the experimental group was effective in helping students develop their reading skills in relation to vocabulary recognition and retention than the conventional course design for the control group, and that students at the experimental group only improved their scores. It can be claimed that there are many advantages of mobile-based reading activities. These include accessibility, usability and functionality. MALL activities are stimulating, motivating, entertaining and even funny. Results indicate clearly that students had a positive attitude towards MALL activities. This even had its positive consequences on their English learning process.

It can be claimed that the significant differences in the achievements of the two groups are attributed to using mobile activities and tasks in their learning of English as a second language. It was a new practice for the students which they liked. MALL activities and systems also encouraged students to be less shy and afraid of making mistakes. In MALL contexts, students are encouraged to learn much better and then improve their achievements. In these contexts, students feel that they were really responsible for their own learning.

The main implication here is that there is correlation between the use of mobile-assisted language learning activities on one side and the students' motivation and improvement on the other side. Students were motivated to learn EFL reading comprehension and this led to an improvement in their reading performance. Letter and vocabulary recognition skills were greatly developed. Participants also in the experimental group were able to understand the reading passages better.

This study represents a preliminary effort to empirically examine the effect of MALL systems and activities on secondary school students' learning of English in the Kingdom of Saudi Arabia. In spite of the empirical evidence obtained in this study, there are some limitations. The study was confined to the Saudi secondary schools and the number of participants was relatively small. Nevertheless, the results are promising and MAA and technology-based instruction methods need to be more extensively used. Extensive training programs are recommended for teachers of English. Teachers too need to develop new teaching practices and strategies that keep students motivated and involved in the learning process. Traditional methods are no longer effective in teaching. Students should not be passive recipients of knowledge. The role of teachers should be that of a facilitator.

It is hoped after all that educational institutions in the Kingdom of Saudi Arabia to set aside the traditional view of knowledge, expertise, and learning. They need to think about information and communication technologies in teaching and learning. They need to enforce the alternative models of education that use emerging technologies to reinvent many aspects of teaching, learning, and schooling. Educational institutions need to create and implement a learning environment or culture that depends on building a strategy that makes the best use of technology and administrated by people who are highly skilled. Future studies also need to address the issue of using latest technology. In recent years, students are more interested in the use of mobiles and tablets in playing games and writing posts (Kim, 2015; Ma, 2015; Steel, 2015). Therefore, more studies are suggested in evaluating mobile-assisted language learning (MALL) systems). Future studies should suggest new strategies that make the best use of available technology in improving students' language skills.

\section{Acknowledgments}

This project was supported by the Deanship of Scientific Research at Prince Sattam Bin Abdulaziz University under the research project 2017/02/8229.

\section{References}

Adler, C. R. (2004). Seven Strategies to Teach Students Text Comprehension. Reading Topics A-Z.

Al Nooh, A., \& Mosson-McPherson, M. (2013). The Effectiveness of Reading Techniques Used in a Saudi Arabian Secondary School Classroom as Perceived by Students and Teachers: A Study of Methods Used in Teaching English and their Effectiveness. Arab World English Journal, 4(3).

Al-Jarf, R. (2007). Developing Reading and Literacy in Saudi Arabia. ERIC Document Reproduction Service, No. ED497944.

Ampa, A. T. (2015). The implementation of interactive multimedia learning materials in teaching listening skills. English Language Teaching, 8(12), 56-56. https://doi.org/10.5539/elt.v8n12p56

Asim, M., \& Majeed, R. (2013). Computer assisted language learning an instrument of change for boosting motivation level among the students of graduation in Pakistan. Language in India, 13(7), 159-170.

Assagheer, K. (2011). English teaching in Saudi Arabia: Status, issues, and challenges. Riyadh: Hala Print Co. 
Bangs, P. (2011). Introduction to CALL authoring programs. In G. Davies (Ed.), Information and Communications Technology for Language Teachers (ICT4LT). Slough: Thames Valley University.

Bates, T. (2014). Teaching in a Digital Age: Guidelines for Designing Teaching and Learning for a Digital Age.

Bax, S. (2011). Normalization revisited: the effective use of technology in language education. International Journal of Computer-Assisted Language Learning and Teaching (IJCALLT), 1(2), 1-15. https://doi.org/10.4018/ijcallt.2011040101

Bhatti, T. M. (2013). Teaching Reading through Computer-Assisted Language Learning. The Electronic Journal for English as a Second Language, 17(2), 1-11.

Birch, B. (2015). English L2 Reading: Getting to the Bottom (3rd ed.). New York; London: Routledge.

Bush, M. D. (2008). Computer-Assisted Language Learning: From Vision to Reality? CALICO Journal, 25(3), 443-470. https://doi.org/10.1558/cj.v25i3.443-470

Ediger, M. (1999). Whole language versus phonics (what is really the issue?). ERIC Document Reproduction Service, No. ED432729.

Gangaiamaran, R., \& Pasupathi, M. (2017). Review on Use of Mobile Apps for Language Learning. International Journal of Applied Engineering Research, 12(21), 11242-11251

Gobel, P., \& Kano, M. (2014). Mobile Natives: Japanese University Students' Use of Digital Technology. In J. B. Son (Ed.), Computer-Assisted Language Learning: Learners, Teachers and Tools. Newcastle upon Tyne: Cambridge Scholars Publishing.

Godwin-Jones, R. (2013). Integrating Intercultural Competence into Language Learning through Technology. Language Learning \& Technology, 17(2), 1-11.

Gupta, P., \& Schulze, M. (2011). Human Language Technologies (HLT). In G. Davies (Ed.), Information and Communications Technology for Language Teachers (ICT4LT). Slough: Thames Valley University.

Hsu, L. (2013). English as a foreign language learners' perception of mobile assisted language learning: a cross-national study. Computer Assisted Language Learning, 26(3), 197-213. https://doi.org/10.1080/09588221.2011.649485

Hubbard, P. (2008). CALL and the Future of Language Teacher Education. CALICO Journal, 25(2), 175-188.

Hubbard, P. (2009). Computer assisted language learning: Critical Concepts in Linguistics. London: Routledge.

Ivers, K. S., \& Barron, A. E. (2014). Digital Content Creation in Schools: A Common Core Approach. ABC-CLIO. California: Libraries Unlimited.

Johnson, E., Perry, J., \& Shamir, H. (2010). Variability in reading ability gains as a function of computer-assisted instruction method of presentation. Computers \& Education, 55(1), 209-217. https://doi.org/10.1016/j.compedu.2010.01.006

Kim, H. (2015). Mobile App Design for Individual and Sustainable MALL: Implications from an Imprical Analysis. In A. M. Sanz, M. Levy, F. Blin, \& D. Barr (Eds.), WorldCALL: Sustainability and Computer-assisted Language Learning. Bloomsbury Publishing.

Knaack, L. (2003). Elements of Effective Instructional Design for Elementary Mathematical Problem Solving Computer Software. Proceedings of Society for Information Technology \&Teacher Education International Conference (pp. 2921-2924).

Krashen, S. D., \& Terrell, T. D. (1983). The Natural Approach: Language Acquisition in the Classroom. Oxford; San Francisco: Preggammon, Almany.

Ma, Q. (2015). An Evidence-based Study of Hong Kong University Students' Mobile Asisted Language Learning (MALL) Experience. In A. M. Sanz, M. Levy, F. Blin, \& D. Barr (Eds.), WorldCALL: sustainability and computer-assisted language learning. Bloomsbury Publishing.

Mahrooqi, R., \& Ardian, R, A. (2014). Focusing on EFL reading: theory and practice. Cambridge: Newcastle upon Tyne, Cambridge Scholars Publisher.

Masadeh, T. (2015). Performance of Saudi English Language Teachers in Reading Comprehension Classes. SAGE Open, October-December, 1-10. https://doi.org/10.1177/2158244015621598

Morris, N. O. (2011). Using technology in the EFL classroom in Saudi Arabia. MA TESOL Collection, Paper 511 . 
Park, Y., Zheng, B., Lawrence, J., \& Warschauer, M. (2014). Technology-enhanced Reading Environments. In H. R. M. Thomas \& M. Warschauer (Eds.), Contemporary Studies in Linguistics: Contemporary Computer-Assisted Language Learning (pp. 267-287). London; New York: Bloomsbury Academic.

$\mathrm{Pu}$, M. (2009). An Investigation of the Relationship between College Chinese EFL Students' Autonomous Learning Capacity and Motivation in Using Computer-Assisted Language Learning. University of Kansas, Kansas, USA.

Sanz, A. M., Levy, M., Blin, F., \& Barr, D. (2015). WorldCALL: sustainability and computer-assisted language learning. Bloomsbury Publishing.

Sato, T., \& Suzuki, A. (2013). Enhancement of automatization through vocabulary learning using CALL: Can prompt language processing lead to better comprehension in L2 reading? ReCALL, 25(1), 143-158. https://doi.org/10.1017/S0958344012000328

Son, J. B. (Ed.). (2014). Computer-Assisted Language Learning: Learners, Teachers and Tools. Newcastle upon Tyne: Cambridge Scholars Publishing.

Son, J.-B. (2009). Internet-Based Language Learning: Pedagogies and Technologies.

Steel, C. (2015). Students' Perspectives on the afordances and Constraints of Using Mobile Devices and Applications for Learning Languages. In A. M. Sanz, M. Levy, F. Blin, \& D. Barr (Eds.), WorldCALL: Sustainability and Computer-assisted Language Learning. Bloomsbury Publishing.

Sun, Z. (2017). Improving the English-speaking skills of young learners through mobile social networking. Computer Assisted Language Learning, 30(3-4), 304-324. https://doi.org/10.1080/09588221.2017.1308384

Yang, J. (2014). Developing EFL Reading Fluency in Upper Elementary Schools in China. University of San Francisco.

\section{Copyrights}

Copyright for this article is retained by the author, with first publication rights granted to the journal.

This is an open-access article distributed under the terms and conditions of the Creative Commons Attribution license (http://creativecommons.org/licenses/by/4.0/). 